\title{
Acute Otitis Media Due to Mucoid Type Streptococcus pneumoniae
}

\author{
D. Marev \\ Departement of Otorhnolaryngology Universiti Hospital "Sv. Marina" - Varna, Bulgaria
}

\begin{abstract}
:
Introduction. Mucoid otitis is known to be caused by mucoid type Streptococcus pneumoniae, and most of them are serotype 3. As the result of the development of antibiotics, these bacteria have been regarded as an unimportant pathogen

Objective: However, recently there have been severe cases in which this pathogen is responsible. We still have many problems to overcome regarding otitis media.

Methods: The study retrospectively reviewed During the period from January 2004 to July 2005 , we treated 25 cases in which the mucoid type S. pneumoniae was isolated.This study was undertaken to investigate whether each episode of recurrent acute otitis media (rAOM) is caused by the same strain of bacteria or different strains at each episode. cases of 25 children with evidence the Departement of Otorhnolaryngology Universiti Hospital "Sv. Marina"-Varna, between January 2004 and March 2005.

Results: In 22 cases in which either PISP or PRSP was the pathogen detected in two consecutive AOM episodes, 15 cases (68\%) were found in which the involved strain differed between the two episodes.

Conclusion: The antibiotic of the first choice against mucoid otitis media is penicillin. If the pathogen would acquire penicillin resistance, treatment of mucoid otitis media may become as difficult as it was in the old days of preantibiotics

Key words: Acute Otitis Media , Mucoid Type Streptococcus pneumoniae
\end{abstract}

Mucoid otitis is known to be caused by mucoid type Streptococcus pneumoniae, and most of them are serotype 3. As the result of the development of antibiotics, these bacteria have been regarded as an unimportant pathogen. However, recently there have been severe cases in which this pathogen is responsible. (1)

We still have many problems to overcome regarding otitis media. Because of the recent prevalence of antimicrobial resistance, there are differing opinions as to how to treat the children with acute otitis media among Otolaryngologists throughout the world. Vaccine development and mucosal immunological defense system have come into focus in recent otitis media research. Another problem is otitis media with effusion. Much information has been accumulated regarding the pathogenesis and treatment of this disease during the last quarter-century, however, we still do not have a precise understanding of this form of otitis media. $(2,3)$ This disease was examined from different points of view, such as epidemiology, genetics, molecular biology, and biochemical analysis. Many clinicians have tried to establish effective treatment of otitis media with effusion using new devices or medicine, and evidence based medicine for otitis media has hus opened a new field. The inner ear dysfunction causing sensorineural hearing loss, cholesteatoma, tympanosclerosis, and adhesive otitis media are the sequelae after the resolution of otitis media. Otolaryngologists believe that more information is required regarding the pathogenesis of these diseases and the reliable treatment of them. $(4,5)$ 


\section{Material and Methods}

During the period from January 2004 to July 2005, we treated 25 cases in which the mucoid type S. pneumoniae was isolated. (6)

This study was undertaken to investigate whether each episode of recurrent acute otitis media (rAOM) is caused by the same strain of bacteria or different strains at each episode. Seventy infants less than 3years of age, having experienced $\mathrm{rAOM}$ for a period shorter than 8 weeks, were selected and included in the present study. The total number of AOM episodes experienced by this group was 282. At each subsequent episode of AOM, otorrhea and nasopharyngeal swabs were taken for bacterial culture and determination of the MIC for antibiotics. $(7,8)$. When S. pneumoniae was identified, its serotype, and its $\mathrm{pbp}$, ermAM, and mefE genes were also investigated to determine the bacterial species and strains. S. pneumoniae was the most frequently cultured bacteria with 26 penicillin-sensitive S. pneumoniae (PSSP), 65 penicillin-insensitive S. pneumoniae (PISP), and 50 penicillin-resistant S. pneumoniae (PRSP). H. influenzae was the next most frequently cultured bacteria of which 65 were sensitive to penicillin, 27 were found to be beta-bactamase-negative-ampicillin-resistant (BLNAR) and 17 were found to be betabactamase positive. Bacteria cultured from each pair of two successive

episodes of AOM were compared as to the identity of the bacteria during the two episodes. In 150 out of 202 pairs $(74 \%)$, the cultured pathogen was different.

\section{Results}

In 22 cases in which either PISP or PRSP was the pathogen detected in two consecutive AOM episodes, 15 cases $(68 \%)$ were found in which the involved strain differed between the two episodes. This study indicates that the pathogen involved in $\mathrm{AOOM}$ is likely to differ at each episode of AOM, not only in cases caused by PSSP, but also in those caused by PRSP.

Acute otitis media (AOM) is a common infectious disease in children. Some children experience recurrent episodes of AOM. Recent investigations demonstrate antigen-specific immunological deficiencies in children prone to AOM. In the present study, the immune responses to non-typeable Haemophilus influenzae (NTHi) and Streptococcus pneumoniae (S. pneumoniae) were further investigated in otitis-prone children and normal children. Forty-eight percent of otitis-prone children exhibited reduced IgG2 levels to $\mathrm{S}$. pneumoniae and $55 \%$ exhibited reduced $\mathrm{IgG}$ levels to NTHi. These data suggest that otitis prone- ness appears to be related to numerous immunological derangements. Pathogen-specific antibodies are a reliable measure of otitis proneness.

Ninety ears (25 patients, aged 3-11 years) affected by secretory otitis media (SOM) were treated by insertion of ventilation tubes (VT). Following insertion of the VT, middle ear air volume of these ears was estimated using an impedance audiometer, at 1,3, and 6 months postoperatively, and every 3 months thereafter. The middle ear air volume, expressed as the compliance value, increased rapidly for the first 3 months followed by a gradual increase thereafter. A great difference among the compliance values of ears was observed, values ranging from over $10 \mathrm{cc}$ to below $1.5 \mathrm{cc}$ at 6 months, postoperatively. Twelve percent of the ears had compliance values of less than $1.5 \mathrm{cc}$, and in this group, CT showed opacified and poorly developed mastoid cells. Although the association of upper respiratory disorders such as chronic sinusitis, nasal allergies and cleft palates were found to be more frequent in cases of ears with smaller compliance values, this was not statistically significant. Small compliance values (middle ear air volume) were correlated with the early onset of acute or secretory otitis media, repeated otorrhea after VT insertion and high recurrence rates after the extrusion of the VT.

\section{Conclusion}

Based on these experiences, we summarized the current status of the mucoid otitis media as follows: The distribution of patients suffering from mucoid otitis media ranged from infants to elderly people; The patients presented with sympoms, of severe earache ,headache, high fever, profuse otorrhea, and aggravation of sensorineural hearing; The relief of the symptoms is usually better and earlier when penicillin was selected as a first choice,whereas when cephem antibiotics were selected, healing of the otitis media tend to be delayed;

As 13 of 14 strains isolated in 2004 were found to be penicillin-insensitive, Streptococcus pneumoniae (PISP) with $\mathrm{pbp} 2 \mathrm{x}$ gene, it is conceivable that the resistance of this pathogen against cephem is under a rapid progress,probably due to abuse of cephem in the past in this country; and

The antibiotic of the first choice against mucoid otitis media is penicillin. If the pathogen would acquire penicillin resistance, treatment of mucoid otitis media may become as difficult as it was in the old days of preantibiotics. We should pay enough attention to this disease as an important reemerging infectious disease in the otolaryngologic field. 


\section{Reference}

1. What Type of Mucosal Defence Failure Precedes an Acute Otitis Media? L.-E. Stenfors, Acta Otolaryngol 1999; 119(6): 703-7

2. Changes in Immunological Factors in Patients with Chronic Otitis Media, D. Jurkiewicz and B. Zielnik-Jurkicwicz; Acta Otolaryngol Suppl 1997; 478: 73-82.

3. Detailed Histologic, Anatomic, and Morphometric Study of the Middle Ear in Sheep to Establish a New Experimental Model, L. Lavinsky and V. Seibel; Acta Otolaryngol Suppl 1995; 471: 67-78

4. Characterization of Mucosal Lymphocytes in Murine Eustachian Tube; S. Kodama, M. Suzuki and G. Mogi; Acta Otolaryngol Suppl 1990; 471: 73-80

5. Immunogenicity of a Recombinant CopB Protein Cloned from the O35E Isolate of Moraxella catarrhalis; D. Liu, S. Baker, K. VanDerMeid and J. McMichael; Nippon Jibiinkoka Gakkai Kaiho 1990 Sep; 93(9): $1347-53$
6. Mucosal Immune Responses Against Intranasal Administration with Recombinant P6 of Haemophilus Influenzae Fused with Recombinant Mutant Cholera Toxin A1 , T. Fukuiwa, S. Fukuyama, N. Tanaka, S. Udaka, C. , Hara, A. Guadiz, Y. Yuki and Y. Kurono; Nippon Jibiinkoka Gakkai Kaiho 2001 Jan; 104(1): 17-23

7. Intranasal Immunization with P6 Afforded Protection in the Murine Model of Otitis Media A. Sabirov, S. Kodama, T. Hirano, K. Maeda, M. Suzuki and G. Mogi, Nippon Jibiinkoka Gakkai Kaiho 2000 Jan; 103(1) : 19-23.

8. Димов, П. Хроничен серозен отит. (Монография),"Ариел", Ст. Загора, 1-95, 1997.

9. Милков М., Д. Марев, В. Томов - Аудиологични стандарти за слухопротезиране на пациента над осемнадесет годишна възраст, Първи национален конгрес по обша медицина (Сборник резюмета) $2005,45-46$ 